\title{
Coexpression of Multiple Acetylcholine Receptor Genes in Neurons: Quantification of Transcripts during Development
}

\author{
Roderick A. Corriveau and Darwin K. Berg \\ Department of Biology, University of California at San Diego, La Jolla, California 92093-0322
}

A large family of genes encoding subunits of nicotinic ACh receptors (AChRs) has been identified in vertebrates and shown to be expressed in the nervous system. The multiplicity of genes raises questions about which gene products coassemble to produce native receptor subtypes and how the expression of receptor genes is regulated in neurons. We report here that five neuronal AChR genes are expressed in the chick ciliary ganglion at both early and late times in development. Quantitative RNase protection experiments demonstrated that at embryonic day 18 (E18) the ganglion contains about 1800 copies of $\alpha 7$ transcript per neuron, 900 copies of $\alpha 3$ transcript per neuron, and 200-300 copies each of $\alpha 5, \beta 2$, and $\beta 4$ transcripts per neuron. The same five genes are expressed at significantly lower levels at E8 but show the same rank order of abundance in transcripts per neuron. Few, if any, transcripts were found for the $\alpha 2, \alpha 4, \alpha 8$, and B3 AChA genes in ciliary ganglion RNA at either E8 or E18. The 6- and 13-fold increases previously reported for two classes of AChRs on the neurons between E8 and E18 approximate the 4-14-fold increases observed here in AChR gene mRNA levels per neuron over the same time period. The $\alpha 3, \alpha 5, \alpha 7$, and $\beta 4$ genes have previously been correlated with subunits of ciliary ganglion AChRs, but the $\beta 2$ gene has not. The abundance of $\beta 2$ transcripts raises the possibility either that the known AChRs in the ganglion have a more complex subunit composition than previously described or that additional receptor subtypes remain to be discovered. Northern blot analysis revealed no changes in transcript pattern for the $\alpha 3, \alpha 5$, and $\beta 4$ genes between E8 and E18; a small change may occur in the transcript pattern for the $\alpha 7$ gene. In situ hybridizations demonstrated that $\alpha 5$ and $\beta 4$ transcripts are expressed in essentially all ciliary ganglion neurons as has been shown previously for the more abundant $\alpha 3$ transcript and inferred for the $\alpha 7$ transcript. The results indicate that neurons can stably coexpress multiple

\footnotetext{
Received Oct. 26, 1992; revised Dec. 21, 1992; accepted Dec. 28, 1992.

We thank Dr. Marc Ballivet (University of Geneva) for kindly providing the $\alpha 2, \alpha 4, \alpha 5, \beta 2$, and $\beta 4$ genomic and cDNAs and unpublished sequence data for the chicken $\beta 3$ gene. We thank Dr. Ralf Schoepfer (University of Heidelberg) for kindly providing the $p C h 35-4, p C h 29-3$, pCh34-1, and $p C h 31-1$ constructs, and our colleagues Drs. R. Thomas Boyd and Ann Vernallis for preparation of the $\alpha 4$ and $\beta 4$ constructs. PC12 RNA and rat $\alpha 7$ sequence information was generously provided by David Johnson and Drs. James Boulter and Stephen Heinemann (Salk Institute). DNA sequencing was done by C. Elly. Ciliary ganglia were dissected by C. Elly, L. Oliva, A. Romigosa, S. Schoonmaker, and T. Yuen. Grant support was provided by NIH (R01 NSI2601 and P01 NS25916) and the California Tobacco Related-Disease Research Program.

Correspondence should be addressed to Darwin K. Berg, Department of Biology 0322, University of California at San Diego, 9500 Gilman Drive, La Jolla, CA 92093-0322.
}

Copyright $\odot 1993$ Society for Neuroscience $0270-6474 / 93 / 132662-10 \$ 05.00 / 0$
AChR genes, including three of the $\alpha$ type, and that transcript levels may be rate limiting for accumulation of AChRs during development.

IKey words: nicotinic receptors, neuronal ACh receptors, ciliary ganglion, ligand-gated ion channels, gene expression, RNase protection, in situ hybridization, transcripts, mRNA]

A substantial contribution to understanding synaptic transmission at the molecular level comes from the recent cloning of gene families encoding subunits of neurotransmitter receptors. Best characterized is the muscle nicotinic $A C h$ receptor $(A C h R)$, which is a ligand-gated ion channel made up of four kinds of subunits arranged in a pentamer (for review, see Schuetze and Role, 1987). Prior to innervation, an embryonic form containing the $\alpha 1, \beta 1, \gamma$, and $\delta$ gene products prevails and is distributed along the muscle fiber. Subsequently, it is replaced by an adult form that contains an $\epsilon$ gene product instead of $\gamma$ and is concentrated at synapses. Numerous studies have examined the devclopmental regulation of $\mathrm{AChR}$ gene expression in muscle, elucidating the roles of innervation, muscle activity, soluble factors, and second messengers (Goldman and Staple, 1989; Kirilovsky et al., 1989; Klarsfeld ct al., 1989; Osterlund et al., 1989; Goldman ct al., 1991; Martinou and Merlie, 1991; Martinou et al., 1991). In contrast, very little is known about the developmental regulation of gene expression for neurotransmitter receptors on neurons and, in most instances, it is not even clear which gene products make up individual receptor subtypes.

Ten genes have been identified on the basis of sequence homology as being neuronal members of the family encoding nicotinic AChR subunits in chick and in rat (for review, sce Sargent, 1993). Seven of these $(\alpha 2-\alpha 8)$ are thought to encode ligandbinding subunits, while the other three $(\beta 2-\beta 4)$ are thought to cncode structural subunits. Expression studies in Xenopus oocytes have confirmed that four of the $\alpha$-type genes and two of the $\beta$-type genes encode functional AChR subunits. The expression studies have also shown that as few as one or two gene products are sufficient to produce functional AChRs in oocytes (Boulter et al., 1987; Ballivet et al., 1988; Deneris et al., 1988; Wada et al., 1988; Duvoisin et al., 1989; Couturier et al., 1990a,b). Studies with subunit-specific monoclonal antibodies ( $\mathrm{mAbs}$ ), however, have indicated that native AChRs on neurons may have a more complex subunit composition (Conroy et al., 1992; Vernallis et al., in press). The number of AChR genes normally coexpressed by individual neurons is not known.

The chick ciliary ganglion provides a useful system for studying the cxpression of neuronal $\mathrm{AChR}$ genes. Two classes of AChRs have been identified on the neurons. One class (mAb 35-AChRs) is located predominantly in synaptic membrane, 
binds $\mathrm{mAb} 35$, and is responsible for mediating nicotinic transmission through the ganglion (Ravdin and Berg, 1979; Jacob et al., 1984; Loring et al., 1984; Halvorsen and Berg, 1986, 1987; Loring and Zigmond, 1987). The other, class ( $\alpha$ Bgt-AChRs) is located primarily in nonsynaptic membrane, binds $\alpha$-bungarotoxin $(\alpha \mathrm{Bgt})$ but not mAb 35, and only recently has been demonstrated to function as a nicotinic receptor (Jacob and Berg, 1983; Smith et al., 1985; Vijayaraghavan ct al., 1992). Subunit analyses of receptors from $18 \mathrm{~d}$ embryos show that mAb 35AChRs as a population contain the $\alpha 3, \beta 4$, and $\alpha 5$ gene products. At least some mAb 35-AChRs have all three kinds of gene products coassembled. $\alpha \mathrm{Bgt}$-AChRs, in contrast, contain $\alpha 7$ gene product but lack $\alpha 3, \beta 4$, and $\alpha 5$ (Vernallis et al., in press).

During development the nicotinic responses of chick ciliary ganglion neurons undergo several changes. Between embryonic day 8 (E8) and $E 16$, the mean response increases six-to eightfold, and the predominant single-channel event $(40 \mathrm{pS})$ becomes longer in duration. In addition, the neurons acquire the ability to regulate their responses in a cAMP-dependent manner (Margiotta et al., 1987a,b; Margiotta and Gurant<, 1989; Engisch and Fischbach, 1990). During the same period, synaptic contacts on the neurons from preganglionic terminals mature in efficacy and morphology, and the neurons innervate their synaptic targets in the periphery. Other major changes in the ganglion at this time are the proliferation of non-neuronal cells and the reduction of the neuronal population by half through naturally occurring cell death (Landmesser and Pilar, 1972, 1974a,b). It is possible that during development cell-cell interactions regulate the expression of $A C h R$ genes in neurons as in muscle (Schuetze and Role, 1987) and thereby change the properties of the $\mathrm{ACh}$ response by changing the receptor subtypes present.

The experiments described here were undertaken to determine which members of the neuronal AChR gene family are expressed in chick ciliary ganglion neurons and whether changes occur in the pattern of expression during development. The results show that most, if not all, ciliary ganglion neurons contain transcripts from four neuronal AChR genes: $\alpha 3, \beta 4, \alpha 5$, and $\alpha 7$. In addition, substantial amounts of $\beta 2$ transcript are present in the ganglion. The fact that $\beta 2$ protein has yct to be identified in ganglionic receptors suggests either that the reported compositions of $\mathrm{mAb} 35-\mathrm{AChRs}$ and $\alpha \mathrm{Bgt}-\mathrm{AChRs}$ are incomplete or that other $A C h R$ species remain to be identificd. The relative increases in AChR mRNA observed during development mimic the increases reported previously for receptor protein. This finding is consistent with the possibility that transcript levels are rate limiting for accumulation of AChRs on the neurons. No evidence was obtained for known AChR genes being turned on or off latc in embryonic development.

\section{Materials and Methods}

$R N A$ probes. Riboprobes were generated for the chicken $\alpha 2, \alpha 3, \alpha 4, \alpha 5$, $\alpha 7, \alpha 8, \beta 2, \beta 3$, and $\beta 4$ genes by "runoff transcription" using T3, T7, or SP6 polymerase (Promega) and appropriate DNA constructs. The $\beta 2$, $\beta 3$, and $\beta 4$ genes are also known as non- $\alpha 1$, non- $\alpha 2$, and non- $\alpha 3$, respectively, while $\alpha 7$ and $\alpha 8$ are also known as $\alpha \operatorname{BgtBP} \alpha 1$ and $\alpha \operatorname{BgtBP} \alpha 2$, respectively (Sargent, 1993). The $\alpha 2$ probe was transcribed from a construct containing 300 nucleotides corresponding to exon 5 and encoding amino acids $96-196$ of the $\alpha 2$ gene. The construct was obtained by subcloning a fragment of an $\alpha 2$ genomic clone (Nef et al., 1988) into pSP65 (Promega). The $\alpha 3$ probe was transcribed from a construct subcloned from pCH35-4 (Schoepfer et al., 1989) into pSP72 (Promega) and contained 384 bases encoding amino acids $315-441$ of the $\alpha 3$ gene. The $\alpha 4$ probe was transcribed from a construct obtained by subcloning a cDNA of 1878 nucleotides (Nef et al., 1988) into pSP72 (Boyd et al., 1988); the construct was linearized to produce transcripts containing 265 bases encoding amino acids 512-599 and 330 bases of $3^{\prime}$ untranslated sequence of the $\alpha 4$ gene. The $\alpha 5$ probe was transcribed from a construct obtained by subcloning a 736 base pair fragment of a fulllength cDNA clone (Couturier et al., 1990b) into pGEM-7Zf(+) (Promega); the construct was linearized to produce transcripts containing 130 bases encoding amino acids 305-347 of the $\alpha 5$ gene. The $\alpha 7$ probe was transcribed from the previously described $\mathrm{pCh} 29-3$ and contained 166 nucleotides encoding amino acids $125-179$ of the $\alpha 7$ gene (Schoepfer et al., 1990). The $\alpha 8$ probe was transcribed from the previously described pCh31-1 and contained 154 nucleotides of $3^{\prime}$ untranslated sequence of the $\alpha 8$ gene (Schoepfer et al., 1990). The $\beta 2$ probe was transcribed from a 216 base pair PCR fragment encoding amino acids 325-396 (Nef et al., 1988) that was cloned into pGEMX-1 (Promega) and sequenced. The $\beta 3$ probe was generated by using sequence information kindly provided by Dr. Marc Ballivet (University of Geneva; M.-C. Hernandez and M. Ballivet, unpublished observations) to amplify a $\beta 3$ cDNA sequence by PCR from chick ciliary ganglion cDNA. A 239 base pair fragment of $\mathrm{N}$-terminal coding sequence was cloned into pSP72, sequenced, and used to generate $\beta 3$ riboprobe. The $\beta 4$ probe was transcribed from a construct obtained by subcloning a $\beta 4$ genomic fragment (Couturier et al., 1990b) into pSP73 (Promega); the construct was linearized to produce transcripts containing 341 bases coding for amino acids $309-421$ of the $\beta 4$ gene.

Antisense riboprobes were transcribed using either carrier-free $\alpha_{-}{ }^{32} \mathrm{P}$ UTP $(800 \mathrm{Ci} / \mathrm{mmol}$; New England Nuclear) for RNase protection experiments and Northern blots $(\alpha 3, \alpha 5$, and $\beta 4)$ or $\alpha-{ }^{35}$ S-UTP $(3000 \mathrm{Ci} /$ mmol; New England Nuclear) for in situ hybridizations. Synthetic sense RNAs complementary to the antisense probes were generated from the $\alpha 3, \alpha 5, \alpha 7, \beta 2$, and $\beta 4$ constructs for use in standard curves. They were trace labeled with $\alpha^{-32}$ P-UTP at a 200-fold dilution in specific activity for quantification. Synthetic sense RNAs were also used in RNase protection experiments to confirm that the $\alpha 2, \alpha 8, \beta 3$ (data not shown), and $\alpha 4$ (Boyd et al., 1991) antisense probes could be protected by the appropriate complementary sequences.

RNA isolation. Embryonated chicken eggs were obtained and incubated as previously described (Boyd et al., 1991). Ciliary ganglia were rapidly dissected from chick embryos at the indicated times and immediately frozen in liquid nitrogen. (For some experiments, E18 samples included RNA pooled from E17-E19.) Total RNA was isolated from the ganglia by homogenization and extraction with an acid guanidinium thiocyanate-phenol-chloroform mixture as previously described (Chomczynski and Sacchi, 1987). RNA concentrations were determined by $\mathrm{OD}_{260}$ and corroborated by ethidium bromide staining in agarose gels. Gel analysis and Northern blots were used to assess integrity of the isolated RNA.

RNA from the rat pheochromocytoma cell line PC12 was kindly provided by D. Johnson and S. Heinemann (Salk Institute) and contained mRNA from several AChR genes including $\alpha 7$ (D. Johnson and J. Boulter, personal communication).

$R$ Nase protection. RNase protection experiments were carried out as previously described (Melton et al., 1984; Ausubel et al., 1989) with minor modifications. Briefly, total ciliary ganglion RNA $(5-20 \mu \mathrm{g})$ or synthetic sense RNA $(0.1-100 \mathrm{pg})$ was annealed to a molar excess of ${ }^{32} \mathrm{P}$-labeled antisense RNA for $5 \mathrm{~min}$ at $85^{\circ} \mathrm{C}$ in $80 \%$ formamide, 40 mM PIPES buffer (pH 6.7), $0.4 \mathrm{M} \mathrm{NaCl}$, and $1 \mathrm{~mm}$ EDTA, and the hybridization was continued for $12-18 \mathrm{hr}$ at $45^{\circ} \mathrm{C}\left(50^{\circ} \mathrm{C}\right.$ in the case of $\beta 2$ ). Single-stranded RNA was digested by incubating for $60 \mathrm{~min}$ at $15^{\circ} \mathrm{C}$ $\left(30^{\circ} \mathrm{C}\right.$ in the case of $\beta 2$ ) with $4 \mu \mathrm{g} / \mathrm{ml}$ DNase-free RNase (Boehringer Mannheim) and $0.4 \mu \mathrm{g} / \mathrm{ml}$ RNase T1. The RNases were then inactivated by treatment with proteinase K and SDS, and the RNA was extracted with phenol/chloroform, precipitated with ethanol, dissolved in $80 \%$ formamide, and electrophoresed in 5\% acrylamide gels containing $8 \mathrm{M}$ urea. The gels were dried onto Whatman $3 \mathrm{MM}$ paper, and signals were quantified directly from the gels using either a Molecular Dynamics PhosphorImager or an Ambis Radioanalytic Imaging System. Dried gels were also exposed at $-70^{\circ} \mathrm{C}$ to Kodak XAR-5 $\mathrm{x}$-ray film using a $\mathrm{Du}$ Pont Cronex intensifying screen. All statistical comparisons were made with unpaired two-tailed $t$ tests.

Northern blots. RNA was fractionated on $1 \%$ agarose gels containing $7.4 \%$ formaldehyde and then was transferred to GeneScreen Plus (Du Pont) according to the manufacturer's instructions. For $\alpha 7$ Northern blot analysis, a gel-purified cDNA containing 908 bases encoding amino acids $179-480$ and 1192 bases of 3 ' untranslated scquence was labeled 


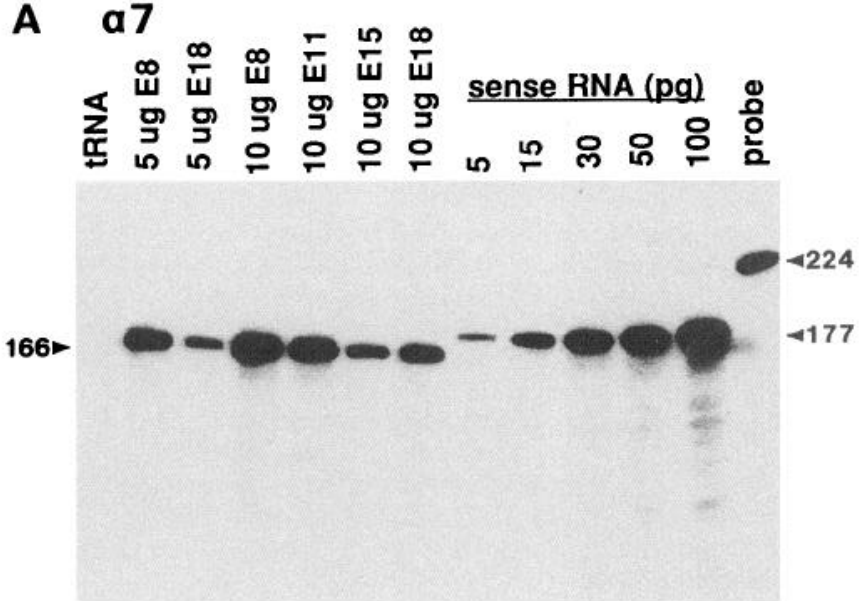

$\begin{array}{lllllllllllll}1 & 2 & 3 & 4 & 5 & 6 & 7 & 8 & 9 & 10 & 11 & 12 & 13\end{array}$
B $\mathbf{a} 3$

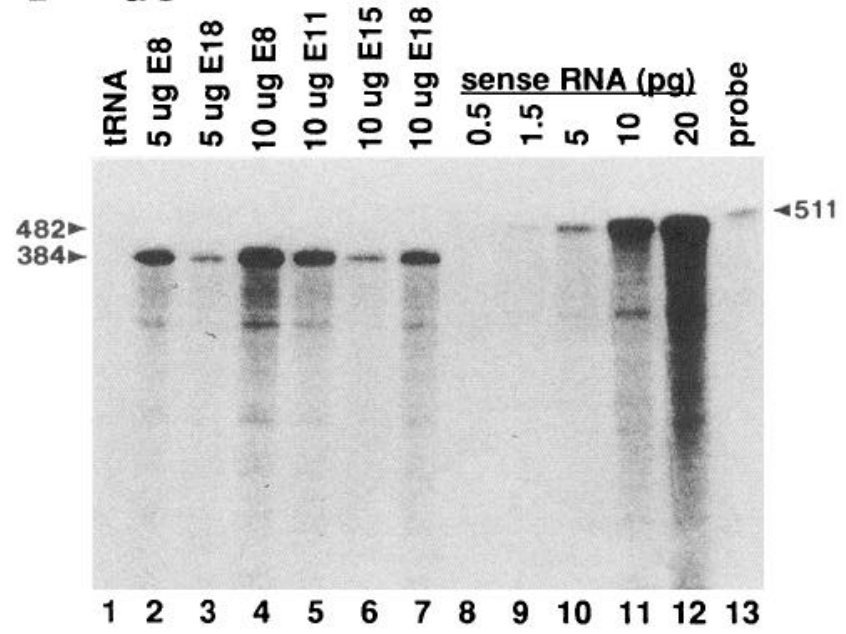

D

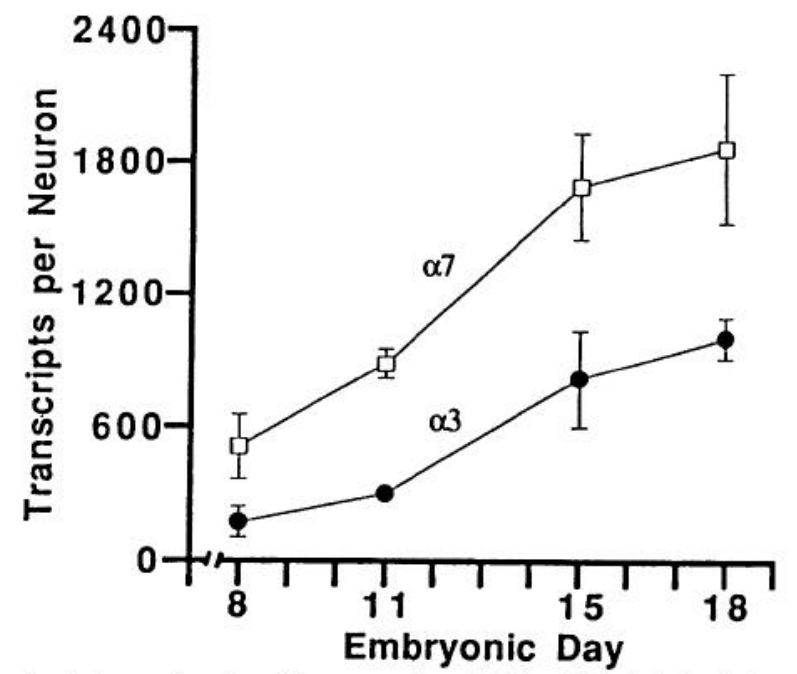

Figure 1. RNase protection experiments quantifying the numbers of $\alpha 3$ and $\alpha 7$ transcripts in ciliary ganglion RNA. ${ }^{32}$ P-labeled single-strand antisense RNA probes complementary to $\alpha 3$ and $\alpha 7$ transcripts were synthesized, isolated, annealed with the indicated RNA sample, digested with RNases, and fractionated by gel electrophoresis. Autoradiographs of gels are shown for $\alpha 7(A)$ and $\alpha 3(B)$ probe protected by $10 \mu \mathrm{g}$ of tRNA (lane 1 ), the indicated ages and amounts of ciliary ganglion RNA (lanes 2-7), and the indicated amounts of complementary synthetic sense RNA (lanes $8-12$ ). The predicted sizes of the undigested probe (lane 13), probe protected by native RNA, and probe protected by synthetic sense RNA are indicated in each case. The amount of radioactivity associated with each species was measured directly from the gel with a Molecular Dynamics PhosphorImager. Signals obtained with the synthetic sense RNA samples yielded linear standard curves for the $\alpha 3$ ( $C$, solid circles) and $\alpha 7$ (open squares) probes. The standard curves were used to convert signals obtained with ciliary ganglion RNA samples to numbers of transcripts, and these values in turn were corrected for the total amount of RNA per ganglion and the number of neurons listed in Table 1 to calculate the number of transcripts per neuron $(D)$. Results represent the mean \pm SEM of three or more determinations except for the $\alpha 3$ E11 value, which averages two determinations. Both the amounts of $\alpha 3$ and $\alpha 7$ transcripts per neuron increase between E8 and E18, with the sharpest increases occurring between E11 and E15.

to about $10^{9} \mathrm{cpm} / \mu \mathrm{g}$ with $\alpha-{ }^{32} \mathrm{P}$-dCTP using a random primers labeling kit (GIBCO/Bethesda Research Laboratories), and filters were prehybridized, hybridized, and washed as recommended (GeneScreen Plus manual). For $\alpha 3, \alpha 5$, and $\beta 4$ Northern blot analysis, filters were probed with antisense riboprobe at $10^{6} \mathrm{cpm} / \mathrm{ml}$, and prehybridization and hybridization procedures were carried out in $50 \%$ formamide, $4 \times \mathrm{SSPE}$, $1 \%$ SDS, $10 \%$ dextran sulfate, $1 \%$ Denhardt's solution, and $100 \mu \mathrm{g} / \mathrm{ml}$ salmon sperm DNA at $60^{\circ} \mathrm{C}$. Nonspecific radioactivity was removed by three $20 \mathrm{~min}$ washes at $65^{\circ} \mathrm{C}$ in $0.2 \times$ saline-sodium citrate (SSC) with $0.1 \%$ SDS. Filters were exposed to Kodak XAR -5 film at $-70^{\circ} \mathrm{C}$ with a Du Pont Cronex intensifying screen.

In situ hybridization. $\alpha 5$ and $\beta 4$ RNA probes labeled with $\alpha-{ }^{35}$ S-UTP were used to detect hybridizing material in sections of frozen tissue using methods previously described (Simmons et al., 1989) with minor modifications. Briefly, $12 \mu \mathrm{m}$ sections were prepared and mounted on poly-L-lysine-coated glass slides, air dried, permeabilized with either
Triton X-100 or proteinase $\mathrm{K}$ treatment, dehydrated with ethanol, and hybridized with labeled RNA probes for $18 \mathrm{hr}$ at $57-59^{\circ} \mathrm{C}$. The sections were incubated with $20 \mu \mathrm{g} / \mathrm{ml}$ RNase A for $30 \mathrm{~min}$ at $37^{\circ} \mathrm{C}$ to digest the residual probe and then washed with a series of SSC solutions of increasing stringency, ending with $0.1 \times \mathrm{SSC}$ at $60^{\circ} \mathrm{C}$. After exposure to Kodak XAR-5 $x$-ray film at room temperature, sections were coated with NTB-2 emulsion, developed, and stained with thionin. Cell counts were performed on nonadjacent sections (to avoid double counting) viewed with a light microscope at $400 \times$ both with bright-field and Nomarski optics. Cells were considered labeled if the grain density over the soma exceeded by at least threefold background labeling over an equivalent area. Background grains per unit area were determined on regions adjacent to labeled cells, for example, over processes and spaces devoid of cells. Photomicrographs were taken with phase-contrast optics. 


\begin{tabular}{rll}
\hline $\begin{array}{l}\text { Table 1. } \\
\text { ganglia }\end{array}$ & RNA yields and neuron counts from embryonic ciliary \\
Age & $\begin{array}{l}\text { RNA } \\
(\mu \mathrm{g} / \text { ganglion })\end{array}$ & $\begin{array}{l}\text { Neurons } \\
\text { (number/ganglion) }\end{array}$ \\
\hline E8 & $0.2 \pm 0.1(2)$ & 6600 \\
E11 & $0.4 \quad(1)$ & 4450 \\
E15 & $1.4 \pm 0.3(3)$ & 3300 \\
E18 & $1.3 \pm 0.4(3)$ & 3200
\end{tabular}

Total RNA was extracted from about 300 (E15 and E18) or about 1000 (E8 and E11) ganglia for each preparation by the method of Chomczynski and Sacchi (1987), quantified by $\mathrm{OD}_{260}$, and expressed as the mean \pm SEM micrograms per ganglion for the number of determinations shown in parentheses. Values for the number of neurons per ganglion were taken from Landmesser and Pilar (1974b).

\section{Results}

Quantification of AChR gene transcripts during development Initial RNase protection experiments revealed transcripts from five AChR genes in ciliary ganglion RNA: $\alpha 3, \alpha 5, \alpha 7, \beta 2$, and $\beta 4$. To determine the absolute amounts present and to compare their levels during development, quantitative RNase protection assays were carried out. Total RNA extracted from ganglia of a given age was hybridized with an excess of ${ }^{32} \mathrm{P}$-labeled antisense probe for the desired gene. After RNase treatment, the products were fractionated by gel electrophoresis and quantified for radioactivity. In each case a standard curve was constructed by using known amounts of synthetic sense RNA to protect the probe and then analyzing the products on the same gel used for the ciliary ganglion RNA samples.

The protection experiments revealed significant amounts of $\alpha 7$ mRNA in ciliary ganglia at each of the stages examined from E8 to E18 (Fig. 1 $A$ ). The signal was specific since it was not obtained when tRNA was substituted for ganglionic RNA. Similarly, rat PC12 RNA, which contains several AChR gene mRNAs including $\alpha 7$, was not able to protect the chicken $\alpha 7$ probe (data not shown). The sizes of the protected species obtained with ciliary ganglion RNA were consistent with those predicted after removal of vector sequences present in the probe (224 bases for undigested probe, 166 bases for probe protected by ciliary ganglion RNA, and 177 bases for probe protected with synthetic sense RNA that contained a residual 11 bases of vector sequence). Doubling the amount of ciliary ganglion RNA in the assay doubled the amount of probe protected, demonstrating proportionality. Similar results were obtained with the $\alpha 3$ probe that also indicated significant amounts of $\alpha 3 \mathrm{mRNA}$ present at all developmental stages examined (Fig. $1 B$ ). Again, the protection was specific and proportional to the amount of ciliary ganglion RNA included in the hybridization.

The amount of protected probe per unit of RNA decreased between E8 and E18, both for $\alpha 7$ and $\alpha 3$ transcripts (Fig. $1 A, B$ ). The amount of total RNA obtained per ganglion, however, increased substantially over the same time period (Table 1). The increase is presumably caused by neuronal growth as well as glial proliferation (Landmesser and Pilar, 1972; Margiotta and Gurantz, 1989). In addition, about half of the neurons are lost between E8 and E14 in the ganglion because of naturally occurring cell death (Landmesser and Pilar, 1974b). Accordingly, a more meaningful comparison over development requires calculating the number of transcript copies per neuron at each stage. To do this it was necessary first to quantify the total amount of transcript present per ganglion using standard curves and then to divide by the number of neurons present.
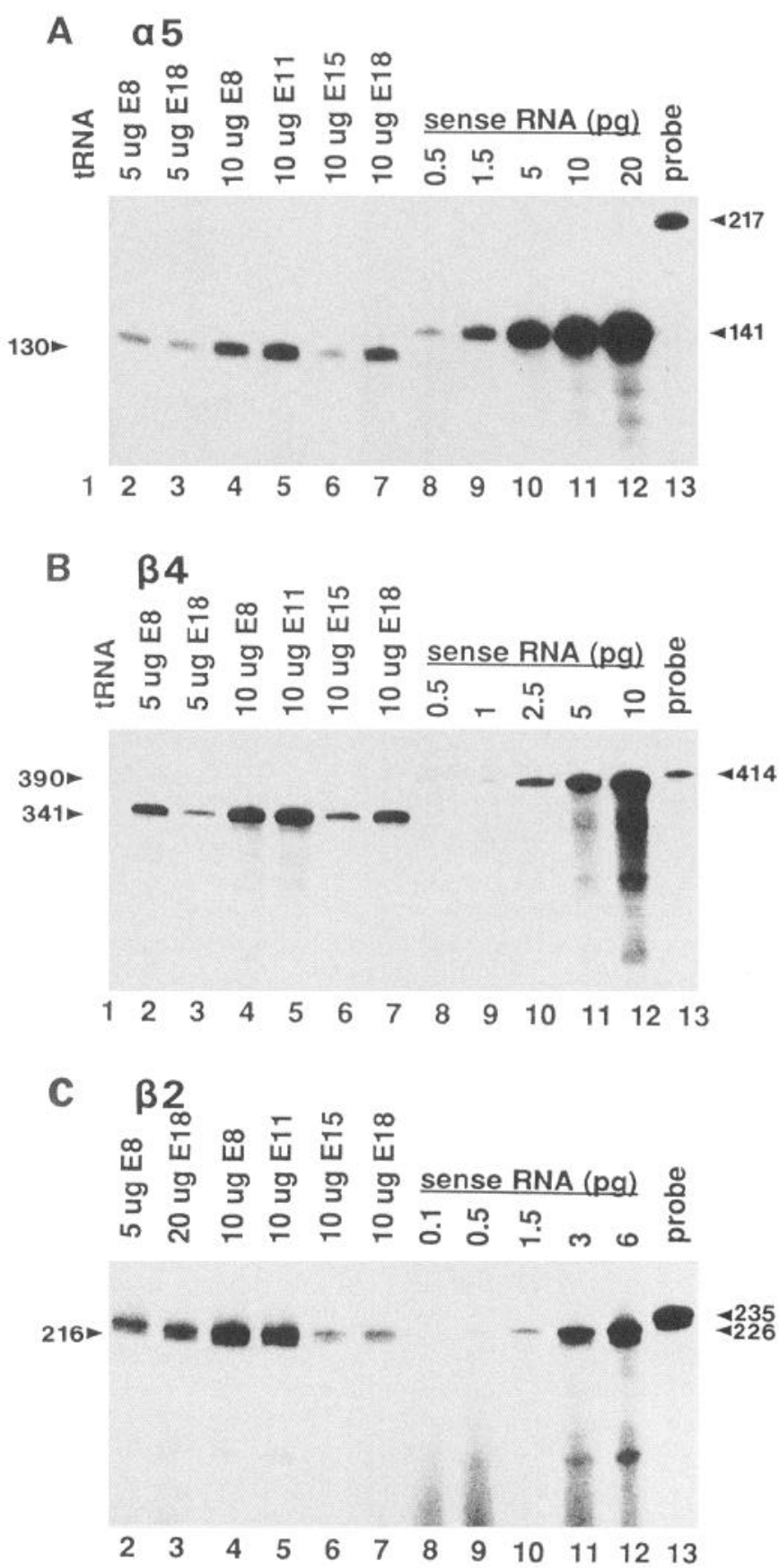

Figure 2. RNase protection experiments quantifying the amounts of $\alpha 5, \beta 4$, and $\beta 2$ transcripts in ciliary ganglion RNA. RNase protection experiments were carried out with ${ }^{32} \mathrm{P}$-labeled $\alpha 5(A), \beta 4(B)$, and $\beta 2$ $(C)$ probes as described in Figure 1 using tRNA, ciliary ganglion RNA, and complementary synthetic sense RNA as indicated. The predicted sizes of the undigested probe, probe protected by native RNA, and probe protected by synthetic sense RNA are indicated in each case. (Though a tRNA lane is not shown for $\beta 2$, all of the protections with synthetic sense RNA included $10 \mu \mathrm{g}$ of tRNA.) Substantial amounts of mRNA from all three genes were detected at each time point examined.

Standard curves generated with $\alpha 3$ and $\alpha 7$ synthetic sense RNA (Fig. $1 C$ ) indicated that the amount of protected probe increased linearly with the amount of RNA over the range tested ( $r$ values $>0.97$ for these and all cases below). The signals obtained with ciliary ganglion RNA samples fell within the linear range of the assay in each of the experiments reported here. 
A

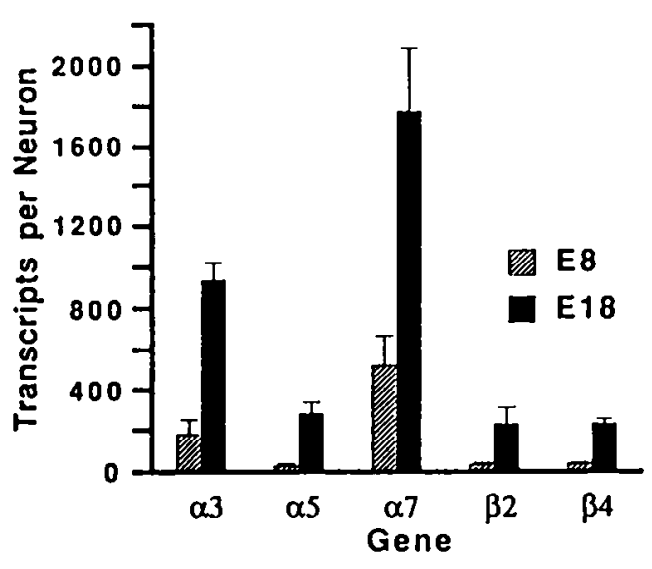

B

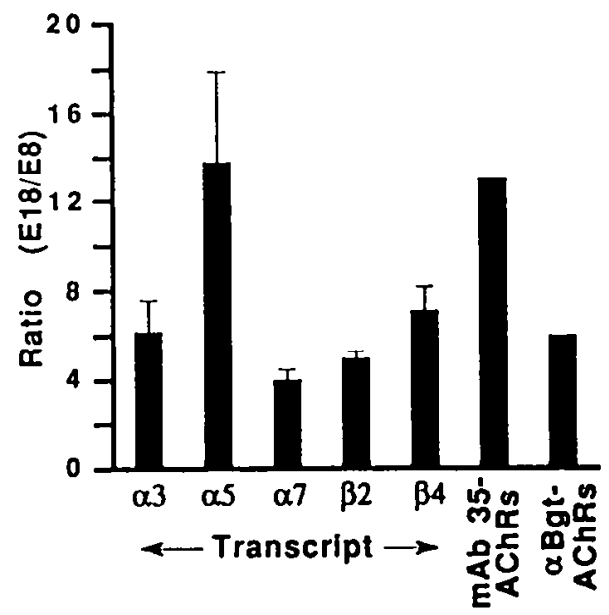

Figure 3. Developmental increases in $\alpha 3, \alpha 5, \alpha 7, \beta 2$, and $\beta 4$ transcripts between E8 and E1 8 in ciliary ganglia. $A$, The numbers of transcript copies per neuron were determined for each of the genes at E8 and E1 8 from experiments such as those shown in Figures 1 and 2 . Results represent the mean \pm SEM of three or more separatc determinations performed on two or three preparations of RNA $(p<0.04$ for E8 vs E18 for $\alpha 3, \alpha 5$, $\alpha 7$, and $\beta 4$; for $\beta 2$ the variation in absolute amounts among experiments necessitated normalizing within experiments as in $B$ to obtain $p<0.01$ for E8 vs E18). At E18, the numbers of $\alpha 7$ and $\alpha 3$ transcripts were each significantly greater $(p<0.01)$ than the numbers of $\alpha 5, \beta 2$, and $\beta 4$ transcripts. $B$, The ratio of transcripts present at E8 and E18 was calculated for each experiment separately and then averaged to obtain a mean $\pm \operatorname{SEM}(n=3$ or more determinations) for each gene. For comparison, ratios for the number of mAb 35-AChRs and for the number of $\alpha$ BgtAChRs per neuron have been calculated from previously reported data (Chiappinelli and Giacobini, 1978; Smith et al., 1985) and are also shown.

The number of transcripts per microgram of ganglionic RNA was determined from the standard curve and then corrected for the total amount of RNA obtained per ganglion (Table 1) and for the number of neurons present, using published values (Landmesser and Pilar, 1974b). The analysis provided values for the mean number of transcript copies per neuron. (Whether all neurons express the transcripts is addressed below.) Presented in this manner, the data show that both the $\alpha 3$ and the $\alpha 7$ transcript levels per neuron increase substantially between E8 and E18 and that most of the increase comes between E11 and $\mathrm{E} 15$ (Fig. $1 D$ ).

Quantitative RNase protection experiments also revealed substantial amounts of $\alpha 5, \beta 4$, and $\beta 2$ transcripts in the ganglion both at E8 and at E18 (Fig. 2). In each case the signal was specific and proportional to the amount of ciliary ganglion RNA used. Standard curves were constructed for each probe and used to quantify the amount of transcript in the ganglionic samples as done above for $\alpha 3$ and $\alpha 7$. At E 18, the $\alpha 5, \beta 4$, and $\beta 2$ transcripts each numbered 200-300 copies per neuron, compared to the approximately 900 copies of $\alpha 3$ and 1800 copies of $\alpha 7$ transcripts per neuron (Fig. 3A). The same rank order of transcript abundance was observed at E8, though the absolute amounts were reduced. In some experiments the amounts of $\alpha 5, \beta 4$, and $\beta 2$ mRNA were also measured at E11 and E15 (Fig. 2). The developmental patterns observed for $\alpha 5, \beta 4$, and $\beta 2$ mRNA were similar to those shown above for $\alpha 3$ and $\alpha 7$ mRNA.

The ratio of transcript copies per neuron at E8 and E18 is shown for each gene in Figure $3 B$. The greatest fold increase occurs in $\alpha 5$ transcripts, which are among the least abundant at both times. The smallest fold increase occurs in $\alpha 7$ transcripts, which are the most abundant at both times. For comparison, the corresponding ratios for the number of $\mathrm{mAb} 35-\mathrm{AChRs}$ and for the number of $\alpha \mathrm{Bgt}-\mathrm{AChRs}$ per neuron were calculatcd from previously reported data (Chiappinclli and Giacobini, 1978; Smith et al., 1985) and are shown as well. Interestingly, both types of receptors increase to approximately the same extent as do some of the corresponding transcripts. Thus $\alpha$ Bgt-AChRs, which are known to contain $\alpha 7$ subunits (Vernallis et al., in press), increase about sixfold between E8 and E18 while $\alpha 7$ transcripts increase about fourfold. Similarly, mAb 35-AChRs, which as a population are known to contain $\alpha 3, \beta 4$, and $\alpha 5$ subunits (Vernallis et al., in press), increase about 13 -fold between E 8 and E1 8 while $\alpha 5$ transcript levels increase about 14fold. The levels of $\alpha 3$ transcripts, which are more abundant than $\alpha 5$, increase only sixfold while the levels of $\beta 4$ transcripts increase about sevenfold. Although the abundance of $\beta 4$ transcripts is comparable to that of $\alpha 5$, a fraction of mAb 35-AChRs may lack $\beta 4$ subunits (Vernallis et al., in press). The results suggest that AChR mRNA levels are rate limiting for accumulation of nicotinic receptors on the neurons during development. The best candidates appear to be the $\alpha 5$ and $\alpha 7$ transcripts for specifying the numbers of mAb 35-AChRs and $\alpha \mathrm{Bgt}-\mathrm{AChRs}$, respectively.

RNase protection experiments were also performed for $\alpha 2$, $\alpha 4, \alpha 8$, and $\beta 3$ transcripts. No $\alpha 2$ or $\alpha 8$ mRNA was detected in RNA from cither E8 or E1 8 ciliary ganglia. Only trace amounts of $\alpha 4$ and $\beta 3$ mRNAs were seen at either time (data not shown). The signals were too low to permit quantification (at least 10 fold less than that observed for $\alpha 5, \beta 4$, and $\beta 2$ ).

The amount of $\beta 2$ transcript reported here is considerably more than that detected previously in preliminary experiments (Boyd et al., 1988). The earlier attempts were compromised by unfavorable signal-to-noise ratios that may have resulted from the high GC content of the $\beta 2$ coding sequence ( $63 \%$ for $\beta 2$ fulllength coding sequence vs $38-46 \%$ for the $\alpha 3, \alpha 5, \alpha 7$, and $\beta 4$ genes). In the present experiments the conditions for hybridization and RNase digestion were adjusted to optimize the signal prior to performing the quantitative determinations. Attempts to reduce backgrounds and resolvc a specific $\beta 2$ signal cither on Northern blots or by in situ hybridization, however, have so far been unsuccessful. As a result, $\beta 2$ had to be omitted in the analysis described below for the other genes. 


\section{Transcript sizes at early and late developmental stages}

The increases in AChR gene mRNA that occur per neuron between E8 and E18 in ciliary ganglia could arise either from increased levels of existing transcripts or from the late appearance of new transcript classes. To determine whether the pattern of transcript sizes changes during development, Northern blots were performed with ciliary ganglion RNA from E8 and E18 embryos. No changes were observed in the sizes or dominant species of $\alpha 3, \alpha 5$, and $\beta 4$ transcripts between E8 and E1 8 (Fig. 4). The $\alpha 3$ probe detected a major species of about 3 kilobases (kb) and a minor one of $1.5-2 \mathrm{~kb}$ at both times while the $\alpha 5$ probe detected a single species of about $3.5 \mathrm{~kb}$ at both times (Fig. 4). Similarly, the $\beta 4$ probe detected a major species of about $2.7 \mathrm{~kb}$ and a minor one of $1.5-2 \mathrm{~kb}$ at both times.

A small difference was observed in the pattern of transcripts detected by the $\alpha 7$ probe. Three classes of transcripts with sizes of about $3,3.5$, and $5.5 \mathrm{~kb}$ were observed both at E8 and E18. Only at E18, however, did the $3 \mathrm{~kb}$ transcript appear to dominate. The $3 \mathrm{~kb}$ transcript in E18 RNA also appeared slightly smaller (ca. $0.1 \mathrm{~kb}$ ) than the comparable species in E8 RNA (three experiments), but the decrease was too small to be considered significant unless corroborated by other techniques.

\section{Distribution of transcripts among ciliary ganglion neurons}

Chick ciliary ganglia contain two classes of neurons in addition to non-neuronal cells. The neurons include choroid neurons that innervate smooth muscle in the choroid layer, and ciliary neurons that innervate striated muscle in the iris and ciliary body. Both populations of neurons have mAb 35-AChRs and $\alpha$ BgtAChRs (Jacob and Berg, 1983; Jacob et al., 1984; Boyd et al., 1991). Since all of the $\alpha$ Bgt-AChRs contain $\alpha 7$ gene product (Vernallis et al., in press), it follows that all of the neurons express this gene. In addition, in situ hybridization experiments have confirmed that essentially all of the neurons express the $\alpha 3$ gene product (Boyd et al., 1988, 1991), as expected from the finding that essentially all mAb 35-AChRs contain $\alpha 3$ subunits (Vernallis et al., in press).

The cellular distributions of $\alpha 5, \beta 2$, and $\beta 4$ transcripts in the ganglion, however, remain open questions. Immunoprecipitation experiments with subunit-specific anti- $\beta 4 \mathrm{mAbs}$ suggest that some mAb $35-\mathrm{AChRs}$ may not have $\beta 4$ subunits (Vernallis et al., in press). The proportion of mAb 35-AChRs containing the $\alpha 5$ gene product also cannot be stated with certainty, though essentially all of the gene product expressed in the ganglion appears to be assembled in the receptors (Vernallis et al., in press). $\beta 2$ protein has not yet been found in the ganglion, probably because of the insensitivity of available antibodies (Vernallis et al., in press). Results presented above indicate that the amounts of $\alpha 5, \beta 2$, and $\beta 4$ mRNA in the ganglion are substantially lower than the amounts of either $\alpha 3$ or $\alpha 7$ mRNA. Accordingly, one possibility that must be considered is that the $\alpha 5, \beta 2$, and $\beta 4$ genes are expressed only in subsets of the ciliary ganglion neurons.

To examine the distribution of $\alpha 5$ and $\beta 4$ expression, in situ hybridization experiments were performed using ${ }^{35} \mathrm{~S}$-labeled probes on cryostat sections of E17 ciliary ganglia. (The distribution of $\beta 2$ transcripts could not be determined because of high backgrounds as indicated above.) The sections were dipped in emulsion, exposed for 2 weeks, and developed to reveal silver grains. Thionin staining was used to enhance visualization of cells. Extensive labeling of ganglionic neurons was observed

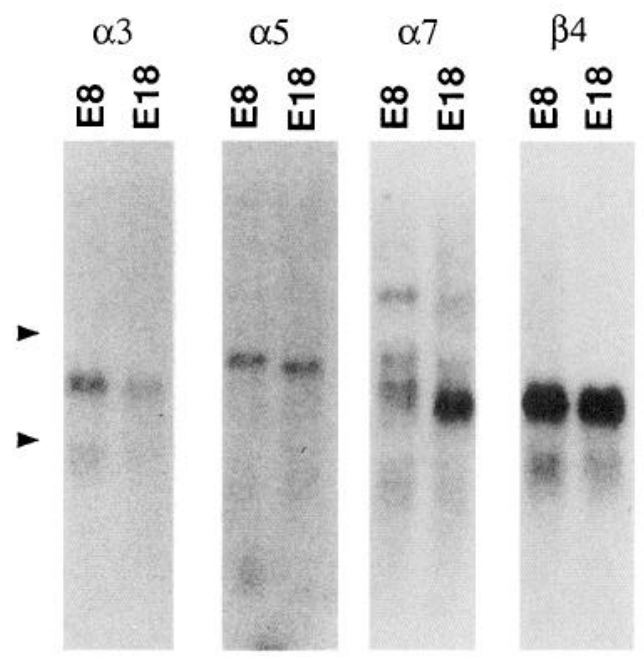

Figure 4. Northern blots of total RNA from E8 and E18 ciliary ganglia hybridized with $\alpha 3, \alpha 5, \alpha 7$, and $\beta 4{ }^{32} \mathrm{P}$-labeled probes. Ciliary ganglion RNA samples from E8 $(5 \mu \mathrm{g})$ and E18 $(10 \mu \mathrm{g})$ were analyzed on Northern blots hybridized with ${ }^{32} \mathrm{P}$-labeled probes to detect the indicated transcripts. The markers indicate the positions of ribosomal RNAs in the E18 samples. E8 samples migrated slightly slower, as indicated by both the positions of the ribosomal E8 RNAs (not shown) and the positions of the AChR transcripts. The transcript patterns were similar for E8 and E18 samples in all cases except for a shift in the distribution of transcripts among the three $\alpha 7$ species.

both with the $\alpha 5$ and with the $\beta 4$ antisense probes (Fig. $5 A, B, D, E$ ). Only background levels of grains were apparent over processes, non-neuronal cells, and extracellular spaces in the sections. The neuronal labeling was specific since it was absent in sections probed with $\alpha 5$ or $\beta 4$ sense probes (Fig. $5 C, F$ ). Labeled neurons included both small, elliptical (about $10 \mu \mathrm{m}$ across) and large, spherical ( $>20 \mu \mathrm{m}$ in diameter) cells having the morphological characteristics of choroid and ciliary neurons, respectively (Landmesser and Pilar, 1974a). Counting the proportion of neurons specifically labeled indicated that $95 \pm 3 \%$ of the ciliary ganglion neurons in E17 embryos (mean \pm SEM of 151 neurons counted from three sections) contain the $\alpha 5$ transcript. Similarly, $97 \pm 2 \%$ (151 neurons, three sections) contain the $\beta 4$ transcript. It can be concluded that ciliary ganglion neurons, including both choroid and ciliary cells, coexpress the $\alpha 3, \alpha 5, \alpha 7$, and $\beta 4 \mathrm{AChR}$ genes.

\section{Discussion}

The major findings reported here show that five neuronal AChR genes are stably expressed in the chick ciliary ganglion during development. Four of the genes $-\alpha 3, \alpha 5, \alpha 7$, and $\beta 4-$ have previously been correlated with receptor proteins in ciliary ganglia, and are expressed in most, if not all, ciliary ganglion neurons. The fifth gene, $\beta 2$, has not previously been recognized as contributing subunits to AChRs in the ganglion but is expressed at levels comparable to the $\alpha 5$ and $\beta 4$ genes. In addition, the results show that the pattern of developmental increases observed for AChR gene transcripts in the ganglion mimics the pattern of increases observed for the numbers of AChRs containing the encoded subunits. No evidence was obtained for expression of some other known member of the neuronal AChR gene family late in development. These results suggest that transcript levels may be rate limiting for accumulation of AChRs and that qualitative changes observed in ACh responses during 


\section{a5}
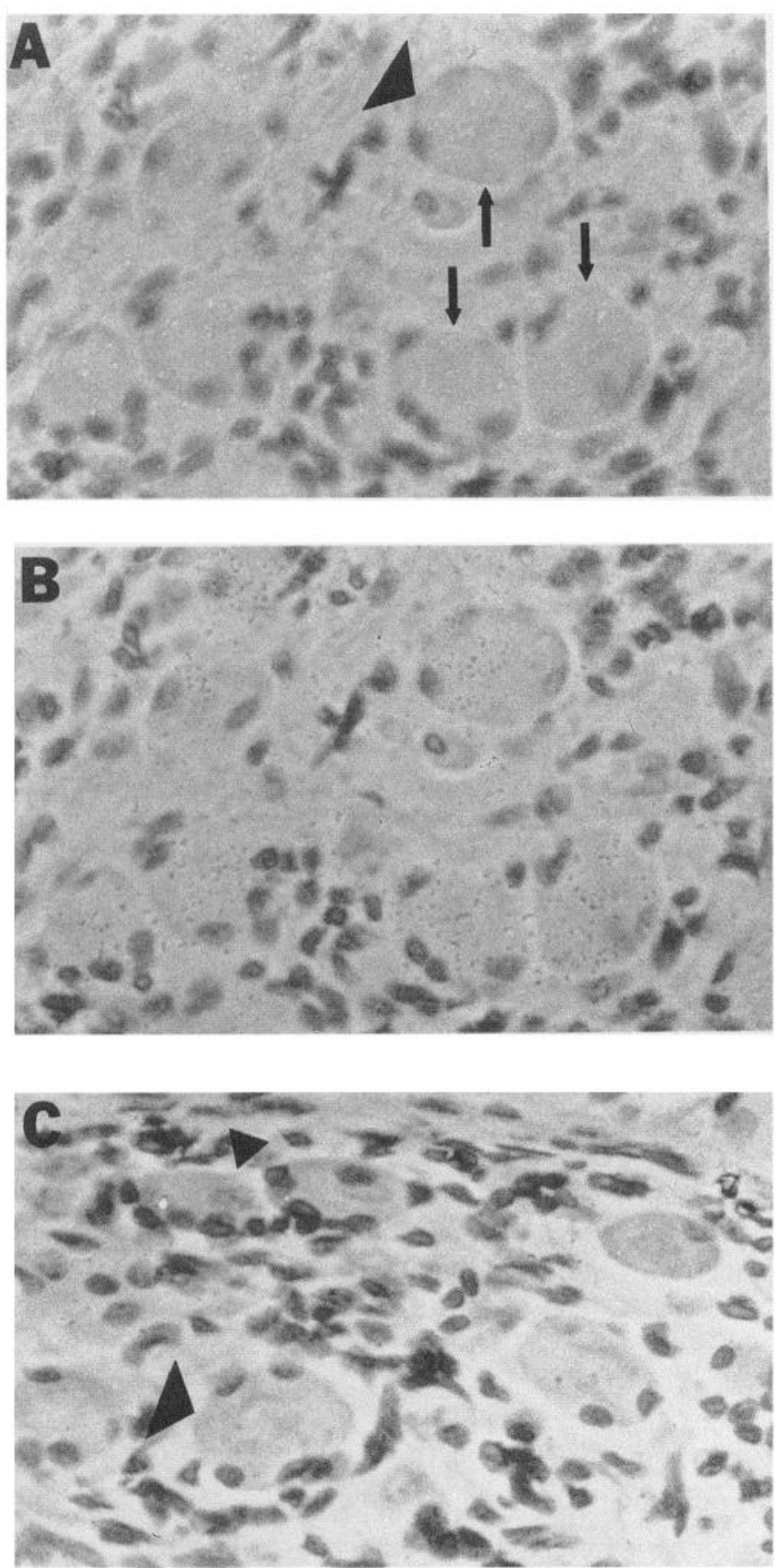

B4
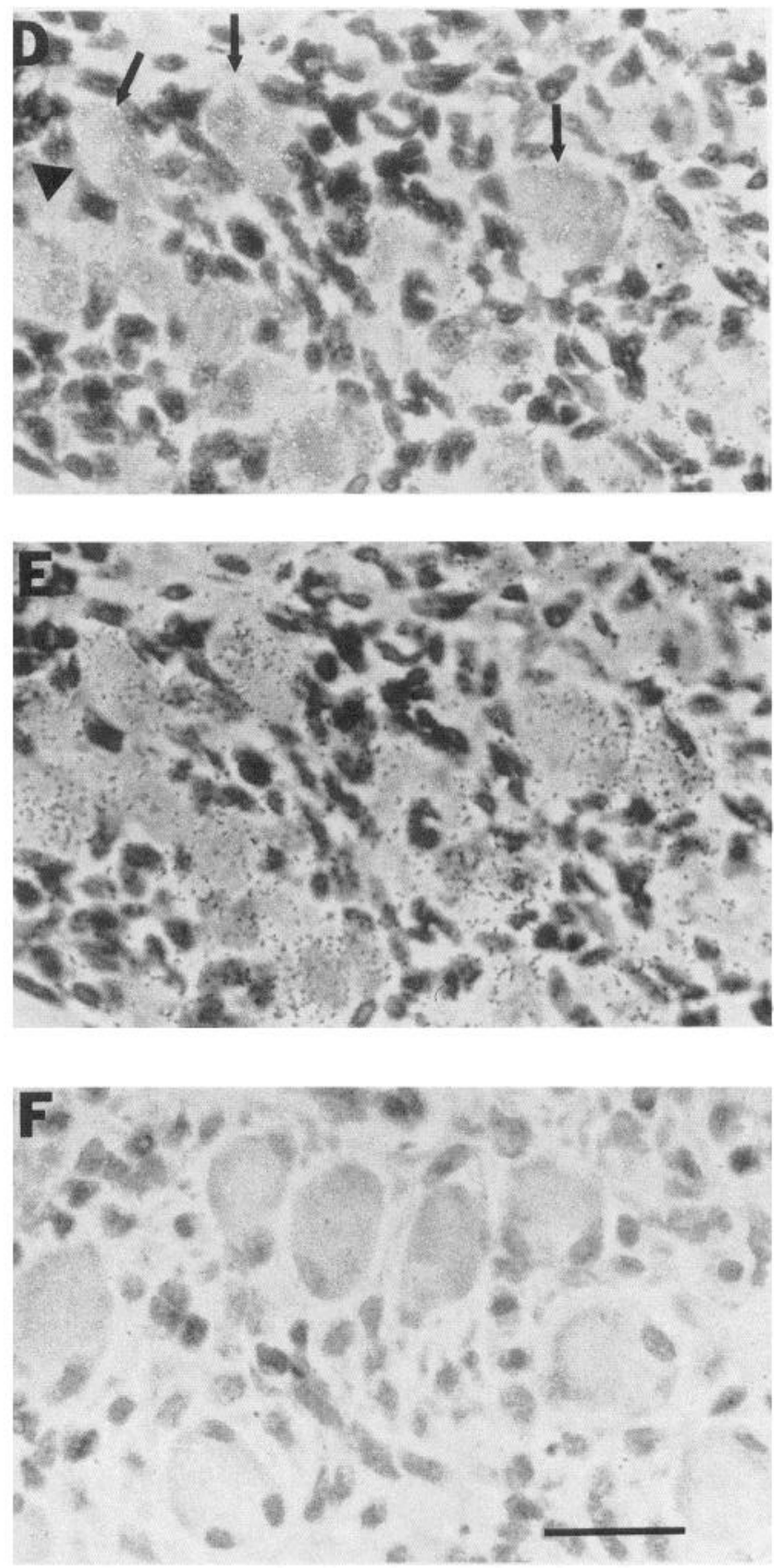

Figure 5. In situ hybridization on chick ciliary ganglion sections with $\alpha 5$ and $\beta 4$ probes. Cryostat sections ( $12 \mu \mathrm{m})$ of E17 ganglia were hybridized with ${ }^{35}$ S-labeled probe, coated with emulsion, developed, stained with thionin, and photomicrographed with phase-contrast optics. $A$ and $B, \alpha 5$ antisense probe; $C, \alpha 5$ sense probe; $D$ and $E, \beta 4$ antisense probe; $F, \beta 4$ sense probe. The cell layer has been chosen as the plane of focus in $A$ and $D$ to distinguish cell bodies, while in $B, C, E$, and $F$ the emulsion layer has been chosen to emphasize grains. $A$ and $B$ are from the same field of view; $D$ and $E$ are from the same field of view. Examples of labeled cell bodies are indicated by arrows. Several putative choroid and ciliary neurons, distinguished by morphological criteria (Landmesser and Pilar, 1974a), are designated by small and large arrowheads, respectively. Scale bar, 25 $\mu \mathrm{m}$.

development are more likely to arise from posttranslational modifications of receptors than from the appearance of new types of AChR subunits.

Quantification of mRNA levels by calibrated RNase protection experiments arguably provides the most reliable method at present for measuring numbers of transcripts per neuron. There is virtually no chance that the probes cross-hybridized to other AChR gene transcripts. In each experiment the coding portion of the probe was protected as an intact species. The $\alpha 3$, $\alpha 5, \beta 2$, and $\beta 4$ probes represent putative cytoplasmic domains having relatively low levels of homology among family members. Even the $\alpha 7$ probe, derived from a putative extracellular domain with more homology, did not cross-hybridize as evidenced by the failure of rat PC12 RNA (including $\alpha 7$ transcript) to protect the chicken probe.

The greatest potential source of error in the quantification 
comes from having to determine the total amount of ganglionic RNA present at various developmental stages. For this reason RNA extractions and determinations were performed separately on two batches of E8 ganglia and on threc batches of E1 8 ganglia. The six- to sevenfold increase in total RNA per ganglion observed between $E 8$ and $E 18$ is very close to the approximately sixfold increase reported in ganglion weight over the same period (Chiappinelli and Giacobini, 1978), making it unlikely that a selective loss of RNA occurred at a given age. Systematic losses of RNA during the extractions would not affect the relative transcript levels reported here. Such losses would, however, lead to an underestimate in the number of transcript copies calculated per neuron.

To evaluate developmental changes in mRNA levels, it is important to compare transcript levels on the basis of copics per neuron. While decreases were seen in the signal per microgram of ganglionic RNA for each of five AChR genes between E8 and E18, substantial increases were obtaincd when the data were expressed as transcripts per neuron. If neuron counts and RNA yields are not taken into account at cach developmental stage, changes in the size of the neuron pool or in the ratio of neurons and non-neuronal cells contributing RNA to the sample can lead to serious errors of interpretation.

The in situ hybridization experiments demonstrate that $\alpha 5$ and $\beta 4$ transcripts are present in essentially all of the neurons as was previously shown for $\alpha 3$ transcripts (Boyd et al., 1988, 1991). Since most, if not all, of the neurons have $\alpha \mathrm{Bgt}-\mathrm{AChRs}$ that contain $\alpha 7$ gene product (Vernallis et al., in press), it can be concluded that most ciliary ganglion neurons coexpress the $\alpha 3, \alpha 5, \alpha 7$, and $\beta 4$ genes. The amount of $\beta 2$ transcript in the ganglion is comparable to the amounts of $\alpha 5$ and $\beta 4$, making it possible that most ciliary ganglion neurons cxpress this gene as well. There is little reason to think that the $\beta 2$ gene might instead be expressed by non-ncuronal cells in the ganglion, but in situ hybridization experiments, when feasible for $\beta 2$, will be useful to confirm a neuronal location for the transcripts.

Not all neuronal AChR genes are expressed in the ganglion. Northern blots and in situ hybridization experiments previously failed to detect $\alpha 2$ transcripts in ciliary ganglia (Boyd et al., 1988). The highly sensitive RNase protection experiments performed here confirmed the absence of $\alpha 2$ transcripts and indicated a lack of $\alpha 8$ transcripts as well. The absence of $\alpha 8$ transcript is consistent with the failure of a subunit-specific anti- $\alpha 8 \mathrm{mAb}$ to detect $\alpha 8$ protein in ciliary ganglion $\alpha$ Bgt-AChRs (Vernallis et al., in press) though the protein is present in a portion of the $\alpha$ Bgt-AChRs found in brain (Schoepfer et al., 1990). RNase protection experiments did detect trace levels of $\alpha 4$ transcript in ciliary ganglia as found previously (Boyd et al., 1988, 1991), but the amounts were too low to quantify reliably with the methods used here. Immunoprecipitation experiments with subunit-specific anti- $\alpha 4 \mathrm{mAbs}$ failed to detect $\alpha 4$ protein in ciliary ganglia (Conroy et al., 1992; Vernallis et al., in press). Trace amounts of $\beta 3$ transcript were also found, but the amounts again were too low to quantify. Anti- $\beta 3 \mathrm{mAbs}$ are not yet available to identify $\beta 3$ protein in cells. The only identified neuronal AChR gene not tested in the present studies was $\alpha 6$ (Sargent, 1993). No sequence information was available for the $\alpha 6$ gene, and no antibodies were available for the encoded protein.

The five AChR genes expressed in the chick parasympathetic ciliary ganglion $(\alpha 3, \alpha 5, \alpha 7, \beta 2$, and $\beta 4)$ are also expressed in chick sympathetic ganglia, judging from Northern blot analysis (Listerud et al., 1991). The relative amounts of the transcripts, however, appear to differ between the two kinds of ganglia. One other difference is that a sixth $\mathrm{AChR}$ gene, $\alpha 4$, produces too few transcripts to quantify in ciliary ganglia while generating levels in sympathetic ganglia that fall in the same range as $\alpha 5$ and $\beta 2$ (Listerud et al., 1991). The greater complexity of AChR gene transcripts in sympathetic ganglia may be responsible for the greater number of AChR single-channel classes observed in sympathetic ncurons (Moss et al., 1989; Listerud et al., 1991) than in ciliary ganglion neurons (Margiotta et al., 1987a; Margiotta and Gurant7, 1989). Both sympathetic and parasympathetic patterns of AChR gene expression differ from that seen in the CNS where each of the known neuronal AChR genes is expressed to varying extents in one or more regions. The predominant AChR transcripts in the CNS include $\alpha 4$ and $\beta 2$, which in part contribute subunits to receptors having high affinity for nicotine (Deneris et al., 1988; Nef et al., 1988; Schoepfer et al., 1988; Wada et al., 1988; Whiting et al., 1991). Few studies have determined the combination of $\mathrm{AChR}$ genes expressed in single cells, however, making it difficult at present to estimate the number of different combinations utilized in the nervous system.

The increases in $\alpha 5$ and $\alpha 7$ mRNAs between E8 and E1 8 in the ciliary ganglion approximate the increases seen in $\mathrm{mAb} 35$ AChRs and $\alpha$ Bgt-AChRs, respectively, suggesting that these transcripts may be rate limiting for accumulation of the receptors. $\alpha 3$ subunits are also found in mAb 35-AChRs, but $\alpha 3$ transcripts are less likely to be rate limiting because they display a smaller increase and are more abundant than the $\alpha 5$ transcripts. Also, previous studies have shown that preganglionic denervation can induce a threefold decline in $\alpha 3 \mathrm{mRNA}$ without changing either the levels of $\mathrm{mAb} 35$-AChRs on the surface of the neurons or the magnitude of the $\mathrm{ACh}$ response (Boyd et al., 1988; Jacob and Berg, 1988; McEachern et al., 1989). $\beta 4$ transcripts also undergo a smaller increase than $\alpha 5$ transcripts but are roughly comparable in number. The possibility that some mAb 35-AChRs may lack $\beta 4$ subunits (Vernallis et al., in press) makes it difficult to assess the rolc of $\beta 4$ mRNA in regulating receptor accumulation. It is not known whether either $\mathrm{mAb} 35$ AChRs or $\alpha$ Bgt-AChRs contain additional kinds of subunits. If $\mathrm{mAb} 35$ is specific for the $\alpha 5$ gene product in native ciliary ganglion AChRs as it is on immunoblots (Conroy et al., 1992; Vernallis et al., in press), it may not be surprising that $\alpha 5$ transcripts could limit the number of mAb 35-AChRs.

The substantial increase in mean $\mathrm{ACh}$ response observed between E8 and E18 (Margiotta and Gurantz, 1989; Engisch and Fischbach, 1990) very likely reflects increases in mAb 35-AChRs on the neurons and therefore derives from the increased levels of AChR mRNAs, as suggested above. Other changes that occur between E8 and E 18 in nicotinic responses include an increase in the duration of the predominant single-channel event and the appearance of a cAMP-dependent mechanism for enhancing the mean response (Margiotta and Gurantz, 1989; Engisch and Fischbach, 1990). Though such changes might be accounted for by the appearance of new AChR subtypes during development as occurs in muscle, neither the RNase protection experiments nor the Northern blot analyses support such a possibility. No differences were observed in the family of AChR genes expressed or in the sizes of gene transcripts encoding known subunits $(\alpha 3$, $\beta 4$, and $\alpha 5$ ) of $\mathrm{mAb} 35-\mathrm{AChRs}$, the receptor population responsible for the recorded nicotinic responses (Margiotta et al., 1987a,b; Vernallis et al., in press). Subtle changes, however, such as RNA processing to change a single nucleotide or exon 
editing to produce a new splice variant of comparable size to existing species, would have gone undetected if the changes occurred in transcript regions outside that corresponding to the probes. Examples of both have been reported for transcripts encoding glutamate receptors and have been shown to produce receptors with significantly different physiological properties (Sommer et al., 1990, 1991). The data also cannot exclude the possibility that some other member of the AChR gene family, yet to be identified, changes in transcription pattern during development.

It is not clear to what extent cell-cell interactions influence the expression of $\mathrm{AChR}$ genes in the neurons and guide the maturation of $\mathrm{ACh}$ sensitivity. $\mathrm{mAb} 35-\mathrm{AChRs}$ first appear on the neurons about $\mathrm{E} 4$ when innervation by the preganglionic input occurs (Jacob, 1991). Removal of either the target tissue at E2 or the preganglionic source of innervation at E4 does not appear to affect adversely either the acquisition of ACh sensitivity by the neurons or the clustering of mAb 35-AChRs on them through E18 (Engisch and Fischbach, 1990, 1992). Postganglionic axotomy of ciliary ganglia in ncwly hatched chicks, however, specifically decreases the $\mathrm{ACh}$ response and the number of surface $\mathrm{mAb}$ 35-AChRs on the neurons (Brenner and Martin, 1976; Jacob and Berg, 1988; McEachern et al., 1989). Both preganglionic denervation and postganglionic axotomy decrease the large pool of intracellular $\mathrm{mAb} 35-\mathrm{AChRs}$ and $\alpha \mathrm{Bgt}-$ $\mathrm{AChRs}$ in the ganglion and reduce the amount of $\alpha 3 \mathrm{mRNA}$ present (Jacob and Berg, 1987; Boyd et al., 1988). Studies in cell culture show that components from the synaptic target tissue can enhance the $\mathrm{ACh}$ sensitivity of ciliary ganglion neurons (Tuttle, 1983; Halvorsen et al., 1991). It will be of interest to determine whether cell-cell interactions either within the ganglion or between the neurons and the periphery drive the increases observed in AChR transcript levels during development.

\section{References}

Ausubel FM, Brent R, Kingston RE, Moore DD, Seidman JG, Smith JA, Struhl K (1989) Current protocols in molecular biology. New York: Wiley.

Ballivet $M$, Nef $P$, Couturier $S$, Rungger D, Bader CR, Bertrand D, Cooper E (1988) Electrophysiology of a chick neuronal nicotinic acetylcholine receptor expressed in Xenopus oocytes after cDNA injection. Neuron 1:847-852.

Boulter J, Connolly J, Deneris E, Goldman D. Heinemann S, Patrick J (1987) Functional expression of two neuronal nicotinic acetylcholine receptors from cDNA clones identifies a gene family. Proc Natl Acad Sci USA 84:7763-7767.

Boyd RT, Jacob MH, Couturier S, Ballivet M, Berg DK (1988) Expression and regulation of neuronal acetylcholine receptor mRNA in chick ciliary ganglia. Neuron 1:495-502.

Boyd RT, Jacob MH, McEachern AE, Caron S, Berg DK (1991) Nicotinic acetylcholine receptor $\mathrm{mRNA}$ in dorsal root ganglion neurons. J Neurobiol 22:1-14.

Brenner HR, Martin AR (1976) Reduction in acetylcholine sensitivity of axotomized ciliary ganglion cells. J Physiol (Lond) 260:159-175.

Chiappinelli VA, Giacobini E (1978) Time course of appearance of $\alpha$-bungarotoxin binding sites during development of chick ciliary ganglion and iris. Neurochem Res 3:465-478.

Chomczynski P, Sacchi N (1987) Single-step method of RNA isolation by acid guanidinium thiocyanate-phenol-chloroform extraction. Anal Biochem 162:156-159.

Conroy WG, Vernallis AB, Berg DK (1992) The $\alpha 5$ gene product assembles with multiple acetylcholine receptor subunits to form distinctive receptor subtypes in brain. Neuron 9:679-691.

Couturier S, Bertrand D, Matter J-M, Hernandez M-C, Bertrand S, Millar N, Valera S, Barkas T, Ballivet M (1990a) A neuronal nic- otinic acetylcholine receptor subunit $(\alpha 7)$ is developmentally regulated and forms a homo-oligomeric channel blocked by $\alpha$-Btx. Neuron $5: 847-856$.

Couturier S, Erkman L, Valera S, Rungger D, Bertrand S, Boulter J, Ballivet M, Bertrand D (1990b) $\alpha 5, \alpha 3$, and non- $\alpha 3$ : three clustered avian genes encoding neuronal nicotinic acetylcholine receptor-related subunits. J Biol Chem 265:17560-17567.

Deneris ES, Connolly J, Boulter J, Wada E, Wada K, Swanson LW, Patrick J, Heinemann S (1988) Primary structure and expression of $\beta 2$ : a novel subunit of neuronal nicotinic acetylcholine receptors. Neuron 1:45-54.

Duvoisin RM, Deneris ES, Patrick J, Heinemann S (1989) The functional diversity of the neuronal nicotinic acetylcholine receptors is increased by a novel subunit: $\beta 4$. Neuron $3: 487-496$.

Engisch KL, Fischbach GD (1990) The development of ACh- and GABA-activated currents in normal and target-deprived embryonic chick ciliary ganglia. Dev Biol 139:417-426.

Engisch KL, Fischbach GD (1992) The development of ACh- and GABA-activated currents in embryonic chick ciliary ganglion neurons in the absence of innervation in vivo. J Neurosci 12:1115-1125.

Goldman D, Staple J (1989) Spatial and temporal expression of acetylcholine receptor RNAs in innervated and dencrvated rat soleus muscle. Neuron 3:219-228.

Goldman D, Carlson BM, Staple J (1991) Induction of adult-type nicotinic acetylcholine receptor gene expression in noninnervated regenerating muscle. Neuron 7:649-658.

Halvorsen SW, Berg DK (1986) Identification of a nicotinic acetylcholine receptor on neurons using an $\alpha$-neurotoxin that blocks receptor function. J Neurosci 6:3405-3412.

Halvorsen SW, Berg DK (1987) Affinity labeling of neuronal acetylcholine receptor subunits with an $\alpha$-neurotoxin that blocks receptor function. J Neurosci 7:2547-2555.

Jacob MH (1991) Acetylcholine receptor expression in developing chick ciliary ganglion neurons. J Neurosci 11:1701-1712.

Jacob MH, Berg DK (1983) The ultrastructural localization of $\alpha$-bungarotoxin binding sites in relation to synapses on chick ciliary ganglion neurons. J Neurosci 3:260-271.

Jacob MH, Berg DK (1987) Effects of preganglionic denervation and postganglionic axotomy on acetylcholine receptors in the chick ciliary ganglion. J Cell Biol 105:1847-1854.

Jacob MH, Berg DK (1988) The distribution of acetylcholine receptors in chick ciliary ganglion neurons following disruption of ganglionic connections. J Neurosci 8:3838-3849.

Jacob MH, Berg DK, Lindstrom JM (1984) A shared antigenic determinant between the Electrophorus acetylcholine receptor and a synaptic component on chicken ciliary ganglion neurons. Proc Natl Acad Sci USA 81:3223-3227.

Kirilovsky J, Duclert A, Fontaine B, Devillers-Thiery A, Osterlund M, Changeux J-P (1989) Acetylcholine receptor expression in primary cultures of embryonic chick myotubes. II. Comparison between the effects of spinal cord cells and calcitonin gene-related peptide. Neuroscience 32:289-296.

Klarsfeld A, Laufer R, Fontaine B, Devillers-Thiery A, Dubreuil C, Changeux JP (1989) Regulation of muscle AChR $\alpha$ subunit gene expression by electrical activity: involvement of protein kinase $C$ and $\mathrm{Ca}^{2+}$. Neuron 2:1229-1236.

Landmesser L, Pilar G (1972) The onset and development of transmission in the chick ciliary ganglion. J Physiol (Lond) 222:691-713.

Landmesser L, Pilar G (1974a) Synapse formation during embryogenesis on ganglion cells lacking a periphery. J Physiol (Lond) 241: $715-736$.

Landmesser L, Pilar G (1974b) Synaptic transmission and cell death during normal ganglionic development. J Physiol (Lond) 241:737749.

Listerud M, Brussaard AB, Devay P, Colman DR, Role LW (1991) Functional contribution of neuronal AChR subunits revealed by antisense oligonucleotides. Science 254:1518-1521.

Loring RH, Zigmond RE (1987) Ultrastructural distribution of $125 \mathrm{I}$ toxin $F$ binding sites on chick ciliary neurons: synaptic localization of a toxin that blocks ganglionic nicotinic receptors. J Neurosci 7:21532162.

Loring RH, Chiappinclli VA, Zigmond RE, Cohen JB (1984) Characterization of a snake venom neurotoxin which blocks nicotinic transmission in the avian ciliary ganglion. Neuroscience 11:989-999. 
Margiotta JF, Gurantz D (1989) Changes in the number, function, and regulation of nicotinic acetylcholine receptors during ncuronal development. Dev Biol 135:326-339.

Margiotta JF, Berg DK. Dionne VE (1987a) The properties and regulation of functional acetylcholine receptors on chick ciliary ganglion neurons. J Neurosci 7:3612-3622.

Margiotta JF, Berg DK, Dionne VE (1987b) Cyclic AMP regulates the proportion of functional acetylcholine receptors on chicken ciliary ganglion neurons. Proc Natl Acad Sci USA 84:8155-8159.

Martinou J-C, Merlie JP (1991) Nerve-dependent modulation of acetylcholine receptor $\epsilon$-subunit gene expression. J Neurosci 11:12911299.

Martinou J-C, Falls DL, Fischbach GD, Merlie JP (1991) Acetyicholine receptor-inducing activity stimulates expression of the $\epsilon$-subunit gene of the muscle acetylcholine receptor. Proc Natl Acad Sci USA 88:7669-7673.

McEachern AE, Jacob MH, Berg DK (1989) Differential effects of nerve transection on the $\mathrm{ACh}$ and GABA receptors of chick ciliary ganglion neurons. J Neurosci 9:3899-3907.

Melton DA, Krieg PA, Rebagliati MR, Maniatis T, Zinn K, Green MR (1984) Efficient in vitro synthesis of biologically active RNA and RNA hybridization probes from plasmids containing a bacteriophage SP6 promoter. Nucleic Acids Res 12:7035-7056.

Moss BL, Schuetze SM, Role LW (1989) Functional properties and developmental regulation of nicotinic acetylcholine receptors on embryonic chicken sympathetic neurons. Neuron 3:597-607.

Nef P, Oneyser C, Alliod C, Couturier S, Ballivet M (1988) Genes expressed in the brain define three distinct neuronal nicotinic acetylcholine receptors. EMBO J 7:595-601.

Osterlund M, Fontaine B, Devillers-Thiery A, Geoffroy B, Changeux J-P (1989) Acetylcholine receptor expression in primary cultures of embryonic chick myotubes. I. Discoordinate regulation of $\alpha-\gamma-$ and $\delta$-subunit gene expression by calcitonin gene-related peptide and by muscle electrical activity. Neuroscience 32:279-287.

Ravdin PM, Berg DK (1979) Inhibition of neuronal acetylcholine sensitivity by $\alpha$-toxins from Bungarus multicinctus venom. Proc Natl Acad Sci USA 76:2072-2076.

Sargent PB (1993) The diversity of neuronal nicotinic acetylcholine receptors. Annu Rev Neurosci 16: in press.

Schoepfer R, Whiting P, Esch F, Blacher R, Shimasaki S, Lindstrom J (1988) cDNA clones coding for the structural subunit of a chicken brain nicotinic acetylcholine receptor. Neuron 1:241-248.
Schoepfer R, Halvorsen SW, Conroy WG, Whiting P, Lindstrom J (1989) Antisera against an acetylcholine receptor $\alpha 3$ fusion protein bind to ganglionic but not to brain nicotinic acetylcholine receptors. FEBS Lett 257:393-399.

Schoepfer R, Conroy WG, Whiting P, Gore M, Lindstrom J (1990) Brain $\alpha$-bungarotoxin binding protein cDNAs and mAbs reveal subtypes of this branch of the ligand-gated ion channel gene superfamily. Neuron 5:35-48.

Schuctzc SM, Role LW (1987) Developmental regulation of nicotinic acetylcholine receptors. Annu Rev Neurosci 10:403-457.

Simmons DM, Arriza JL, Swanson LW (1989) A complete protocol for in situ hybridization of messenger RNAs in brain and other tissues with radiolabeled single-stranded RNA probes. J Histotechnol 12: 169-181.

Smith MA, Stollberg J, Lindstrom JM, Berg DK (1985) Characterization of a component in chick ciliary ganglia that cross reacts with monoclonal antibodies to muscle and electric organ acetylcholine receptor. J Neurosci 5:2726-2731.

Sommer B, Keinanen K, Verdoorn TA, Wisden W, Burnashev N, Herb A, Kohler M, Takagi T, Sakmann B, Secburg PH (1990) Flip and flop: a cell-specific functional switch in glutamate-operated channels of the CNS. Science 249:1580-1585.

Sommer B, Kohler M, Sprengel R, Seeburg PH (1991) RNA editing in brain controls a determinant of ion flow in glutamate-gated channels. Cell 67:11-19.

Tuttle JB (1983) Interaction with membrane remnants of target myotubes maintains transmitter sensitivity of cultured neurons. Science 220:977-979.

Vernallis AB, Conroy WG, Berg DK (in press) Neurons assemble acetylcholine receptors with as many as three kinds of subunits and can segregate subunits among receptor subtypes. Neuron, in press.

Vijayaraghavan S, Pugh PC, Zhang Z-w, Rathouz MM, Berg DK (1992) Nicotinic receptors that bind $\alpha$-bungarotoxin on neurons raise intracellular free $\mathrm{Ca}^{2+}$. Neuron 8:353-362.

Wada K, Ballivet M, Boulter J, Connolly J, Wada E, Deneris ES, Swanson LW, Heinemann S, Patrick J (1988) Functional expression of a new pharmacological subtype of brain nicotinic acetylcholine receptor. Science 240:330-334.

Whiting PJ, Schoepfer R, Conroy WG, Gore MJ, Keyser KT, Shimasaki S, Esch F, Lindstrom JM (1991) Expression of nicotinic acetylcholine receptor subtypes in brain and retina. Mol Brain Res 10:61-70. 